\title{
Anion Selective Colorimetric Chemosensor with Nitronaphthalene Urea Derivative
}

\author{
Kyung Sin Kìm, Su Yeon Kang, Hyoung Min Yeo, and Kye Chun Nam”
}

\author{
Department of Chemistry, Chonmam National University, Gwangit 500-757, Korea. "E-mail: kcham(a)chonnamac.kn \\ Received July 25, 2007
}

Key Words : Color change, Anion sensor, Fluoride chemosensor, Urea derivative

Anions play an important role in a wide range of chemical and biological processes, and considerable attention has been focused on the design of host molecules that can recognize and sense anion species selectively through the naked eye, electrochemical, and optical responses..$^{1.2}$ Color changes, as signaling an event detected by naked eye, are widely used owing to the inexpensive equipment required or no equipment at all. Those chemosensors are constructed according to the receptor-chronophore binomial, which involves the binding a specific anion substrate with receptor sites and a chromophore responsible for translating the receptor-anion association into an optical signal. ${ }^{3.7}$

Among the important anions, fluoride is of particular interest owing to its established role in preventing dental caries" and acetate for the biological importance. Even though some receptor compounds for fluoride have reported. ${ }^{y \cdot 11}$ there is a paucity of reports on a selective naked eye chemosensor for those anions. ${ }^{12.13}$ Most of those chemosensors have been constructed based on nitrophenyl group as a signal unit. ${ }^{14}$ In pursuit of naked-eye fluoride ion chemosensors a new nitronaphthalene urea derivative 1 was synthesized and its anion binding properties were investigated by UV-vis spectroscopy, 'H NMR and color changes. Ligand 1 showed a significant bathochromic shifts in the presence of fluoride, indicating that it could be utilized as a naked eye chemosensor owing to the noticeable color change in the presence of fluoride ion.<smiles>[2H]c1c(C)c(C)c(NC(=O)Nc2c(C)c(C)c([N+](=O)[O-])c3c(C)c(C)c(C)c(C)c23)c2c([N+](=O)[O-])cccc12</smiles>

Results and Discussion

Ligand 1 was synthesized from the reaction of 4-nitro-1aminonaphthalene with the corresponding isocyanate which was prepared by the reaction of 4-nitro-1-aminonaphthalene with triphosgene in $72 \%$ yield. The $H$ NMR spectrum of ligand 1 showed one characteristic singlet at $\delta 10.01$ for two $\mathrm{N}-\mathrm{H}$ protons and two multiplets at $\delta 7.83-7.93$ and $\delta 8.37-$ $8.64 \mathrm{ppm}$ for twelve aromatic protons.

The UV-vis experiments were carried out in a DMSO solution. A receptor solution $\left(3 \times 10^{-5} \mathrm{M}\right)$ was treated with the representative anions such as tetrabutylammonium (TBA) fluoride, chloride, bromide, acetate and benzoate. When compound $\mathbf{1}$ forms a complex with $\mathbf{F}^{-}$, the absorption peak at $401 \mathrm{~nm}$ disappears and a new peak appears at 535 nm with a red-shifted by a $\Delta \lambda_{\max }$ of $134 \mathrm{~nm}$. When acetate and benzoate form a complex with ligand 1 , the absorption peak at $401 \mathrm{~nm}$ disappears and a new peak appears at 52 1 ntn with a red-shifted by a $\Delta \lambda_{\max }$ of 120 nn. However, a bathochromic shift of other ions such as chloride and bromide was also observed with a small change as shown in Figure 1.

A color change could be observed easily by mixing the ligand and anion as shown in Figure 2. A receptor solution was simply treated with various anions such as $\mathrm{F}^{-}, \mathrm{Cl}^{-}, \mathrm{Br}^{-}$, $\mathrm{I}^{-}, \mathrm{H}_{2} \mathrm{PO}_{4}^{-}, \mathrm{HSO}_{4}^{-}, \mathrm{CH}_{3} \mathrm{COO}^{-}$and $\mathrm{C}_{6} \mathrm{H}_{5} \mathrm{COO}^{-}$. Noticeable color changes were observed when ligand 1 was treated with the anions. In particular, it was remarkable that a pale yellow ligand solution became red when fluoride ions were added to compound 1 in DMSO, but no color changes were observed when the other anions such as chloride, bromide and hydrogen sulfate were added. A similar red color was observed when acetate and benzoate were added into the ligand solution.

To look into the nature of a new peak in the presence of fluoride, NMR titration was carried out. The 'H NMR spectrum of 1 shows dramatic changes in the presence of $\mathrm{F}^{-}$. When $\mathrm{F}^{-}$is added, a amide $\mathrm{N}-\mathrm{H}$ at signal disappear rapidly,

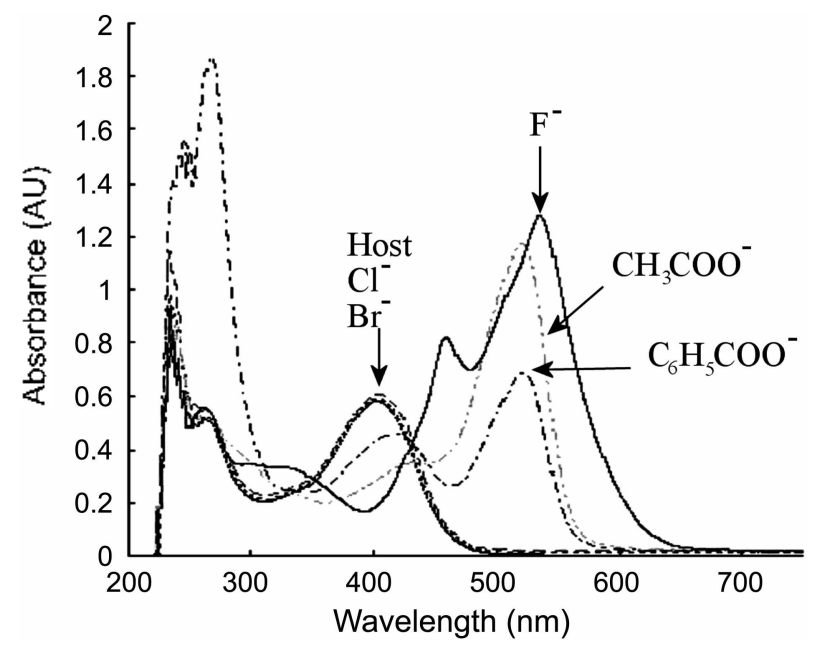

Figure 1. Absorption spectra of compound $1\left(3 \times 10^{-5} \mathrm{M}\right)$ upon addition of tetrabutylammonium chloride, bromide, acetale, benzoate and fluoride $\left(3 \times 10^{-3} \mathrm{M}\right)$ in DMSO. 


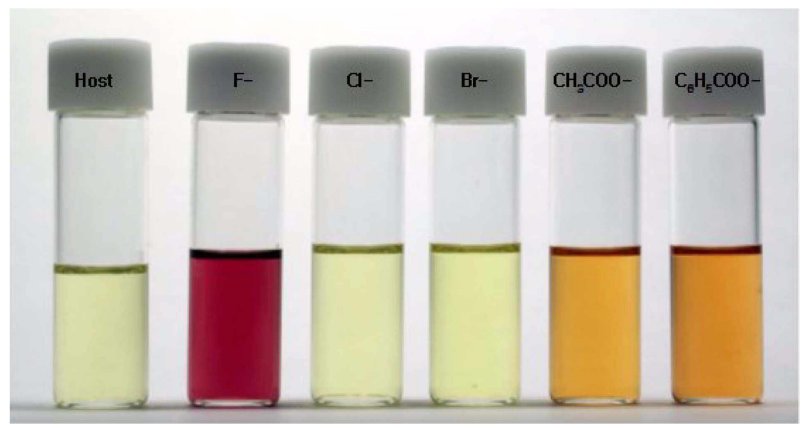

Figure 2. Color changes of ligand $1\left(3 \times 10^{-5} \mathrm{M}\right)$ in $\mathrm{DMSO}$ with the addition of tetrabutylammonium anions $\left(3 \times 10^{3} \mathrm{M}\right)$. From left, Free receptor, Fluoride, Chloride, Bromide, Acetate, and Benzoate.

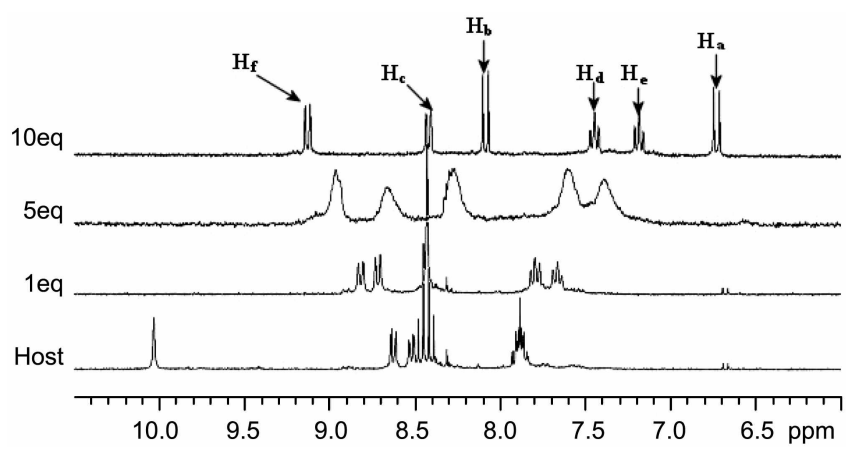

Figure 3. A partial ' $H$ NMR spectra of ligand $\mathbf{l}$ in the presence of fluoride ions in $\mathrm{DMSO}-\mathrm{d}_{t}$. Numbers on left indicale the equivalents of fluoride ions added.

and aromatic protons signals shift downficld or upficld. The correlation spectrum of $2 \mathrm{D}$ COSY indicates that $H_{a}$ is correlated with $H_{1}$, while $H_{s}$ and $H_{l}$ with $H_{4}$ and $H_{s} . H_{a}$ protons at ortho of urea group show a significant up-filed shifi $(\Delta \delta=-1.80)$ upon addition of $\mathrm{F}^{-}$.

$\mathrm{H}_{\mathrm{b}}$ proton signal shows a slight up-ficld shift $(\Delta \delta=-0.30)$, and also moderate up-field shifts are observed from $\mathrm{H}_{\mathrm{d}}$ and $\mathrm{H}_{4}$ proton signals ( $\Delta \vec{\delta}=-0.80$ and -0.60 , respectively). On the other hand, a considerable down-field shift of $\mathrm{H}_{i}$ signal

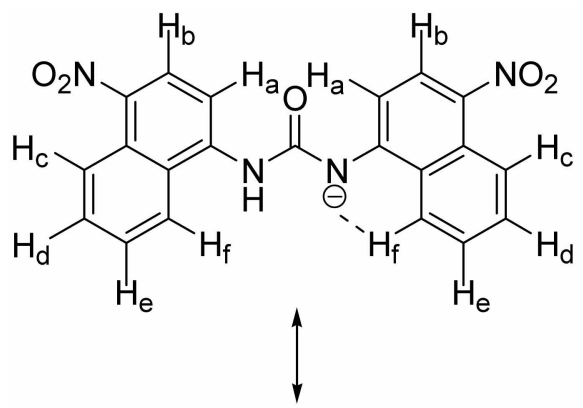<smiles></smiles>

was observed $(\Delta \vec{b}=+0.60)$ as shown in Figure 3. A significant up-field shift of $H_{a}$ and $H_{c}$ protons could be the results of the enlaned resonance of naphthalene from the anionic character of urea nitrogen. A considerable down-field shift of $H_{f}$ signal $(\delta \delta=+0.60)$ could suggest that nitrogen anion formed a cyclic $\mathrm{H}$-bond directly with $\mathrm{H}_{\mathrm{i}}$ proton.

\section{Summary}

A new nitronaphthalene urea derivative 1 was synthesized by the simple reaclion of 1-naphthylamine and its corresponding isocyanate. A distinct color change was observed when ligand I was treated with fluoride ions by extending the conjugated system of the ligand anion which is formed only when complexed with a fluoride ion.

\section{Experimental}

1,3-Bis(4-nitronaphthalen-1-yl)urea (1). To at solution of 1-amino-4-nitronaphthalene $(0.188 \mathrm{~g}, 1.0 \mathrm{mmol})$ in $30 \mathrm{~mL}$. of dry 1,4-dioxane, 0.894 g (3.0 mmol) of triphosgene was added and the reaction mixture was refluxed for 20 hours under the nitrogen atmosphere. Solvent was removed completely under the vacuum condition. The residue was treated with 1-amino-4-nitronaphthalene $(0.188 \mathrm{~g}, 1.0 \mathrm{mmol})$ in 20 $\mathrm{mI}$ of dry 1,4-dioxane. The reaction mixture was refluxed for 24 hours under the nitrogen atmosphere. The precipitate was collected to give $0.292 \mathrm{~g}(72 \%)$ of $1,3-$ bis(4-nitronaphthaten-1-yl)urea; ${ }^{i} \mathrm{H}$ NMR (DMSO-d $\left.\mathrm{d}_{6}\right) \delta 10.01\left(\mathrm{~s}, 2 \mathrm{H}_{4} \mathrm{NH}\right.$ ), 7.83-7.93 (m, 4H, ArH), 8.37-8.64 (m, 8H, ArH).

Acknowledgment. This work was supported by the Ministry of Tducation of Korea ( BK 21 project).

\section{References}

1. Silmamolecular Chemisty of Anions; Bianchi, E.; Bownan-laınes, K.; Garcia-Espana, Г., Гds, Wiley-VClI: New York, 1997.

2. Martincz-Mance, R.; Sancenon, F. (hem. Rev: 2003, 103, 4419.

3. (a) Dielrich, B. Pute Appl. (hem. 1993, 65. 1457. (b) Costero, A. M.; Peransi, S.: Gil, S. Tetrahedron Lett. 2006. 47, 6561 .

4. (a) Atwood, J. L.; Holman, K. T.; Steed, J. W. Chem. Commm. 1996, 1401. (b) Lin, Z;; Ou, S.; Duan, C; Zhang, B.; Bai, Z. Chen. Commum. 2006.624.

5. (a) Gale, P. A. Coonl. Chem. Rev, 2001, 2/3. 79. (b) Guntlaugsson, T.; Kruger, P. E.; Jensen, P.; Tierney, J.; Nli, I1.; H lussey, (i . M. .J. Org. Chem. 2005, 70, 10875.

6. Beer, I'. D.; Gale, I?. A. Angert Chem. Int. Ed. 2001, 40, 486.

7. Cho, E. J.; Ryu, B. J.; Yeo, H. M.; Lee, Y. J.; Nam, K. C. Bull. Korean Chom. Soc. 2005, 26, 470.

8. Kirk. K. I. Biochemistry' of the llatogens and Inorganic Halddes; Plenum Press: New York, 1991: 58.

9. Klecrekoper, M. Endoctimol. Wetab. Clin. North Am. 1998, 27. 441 .

10. (a) Wiseman. A. Hondboth of Experimental Pharmasology $X X / 2$. ['art 2; Springer-Verlag: Berlin, 1970; pp 48-97. (b) Weatherall, J. A. Pharmacologe of Fluorides in Handbook of Experimental Phamacologv XX/1, Part I; Springer-Verlag: Berlin, 1969: pp 14|-172. (c) Dreisbuch. R. 11. Handbook of Poisonimg: Lange Medical P'ublishers: Los Altos, CA, 1980.

11. (a) Dusemund, C.; Sandanayake, K. R. A. S.; Shinkai, S. J. Chem. 
Soc. Chem Commun. 1995, 333. (b) Yamamoto, H.; Ori, A.; Ueda, K.; Dusemund, C.; Shinkai, S. Chem. Commun. 1996, 407. (c) Scherer, M.; Sessler, J. L.; Gebauer, A.; Lynch, V. Chent. Commun. 1998, 85. (d) Anzenbacher, Jr. P.; Jursiková, K.; Lynch, V. M.; Gale, P. A.; Sessler, J. L. J. Am. Chem. Soc. 1999, I2l, 11020. (e) Nicolas, M.; Fabre, B. S. J. Chem. Commun. 1999, 1881. (f) Camiolo, S.; Gale, P. A. Chem. Conmum. 2000, 1129. (g) Lee, D. H.; Im, J. H.; Lee, J. H.; Hong. H. I. Tetrahedron Left. 2002, 43, 9637. (h) Yun, S.; Ihm, H.; Kim. H. G.; Lee, C. W.; Indrajit, B.; Oh, K. S.; Gong, Y. J.; Lee, J. W,; Yoon, J.; Lee, H. C.; Kim, K. S. J. Org. Chem, 2003, 68, 2467.
12. (a) Boiocchi, M.; Boca, L. D.; Gomez, D. E.; Fabbrizzi, L.; Licchelli, M.; Monzani, E. J. Ant. Chent. Soc. 2004, 126, 16507. (b) Miaji, H.; Sessler, J. L. Angew: Chent. Int. Ed. 2001, 40, 154. (c) Jose, D. A.; Kumar, D. K.; Ganguly, B.; das, A. Org. Lett. $2004,6,3445$.

13. Cho, E. J.; Yeo, H. M.; Ryu, B. J.; Jeong, H. A.; Nam, K. C. Bull. Korean Chem. Soc. 2006, 27, 1967.

14. (a) Cho, E. J.; Ryu, B. J.; Lee, Y. J.; Nam, K. C. Org. Lett. 2005, 7 , 2607. (b) Esteban-Gomez, D.; Fabbrizzi, L.; Licchelli, M. J. Org. Chem, 2005, 70, 5717. (c) Esleban-Gomez, D,; Fabbrizzi, L.; Licchelli, M.; Sacchi, D. J. Mater. Chem, 2005, 15, 2670. 